\title{
COVID-19 and Prisoners
}

Anonymous from Saskatchewan Penitentiary

\begin{abstract}
lack of oversight and the absence of checks and balances keeps people - in prison at the mercy of a racist and oppressive institution during COVID-19. Segregation has never been abolished within these walls. The entire population is frequently under 20 -hour cell confinement with 1 -hour outdoor recreation every second day. From March $27^{\text {th }}$ to April $22^{\text {nd }}$, we did not have access to purchase hygiene items from our commissary. We were only provided a single bar of soap on April $14^{\text {th }}$ to sanitize our hands, wash our bodies, as well as clean our utensils and dinnerware. We are fed sub-standard meals in our cells on Styrofoam plates. Despite a substantial increase of garbage, we are still only supplied two small garbage bags per week. As I write this message in April, Saskatchewan Penitentiary still only has one video visitation monitor for over 500 prisoners to connect with loved ones and we have been denied when we ask for more monitors to be installed. The institution has made very small attempts to reduce the population. We have requested numerous concessions to help provide relief, only to be met with firm demurral. Correctional Service Canada staff have even gone as far as threatening complainants. All of us here are deeply concerned regarding our physical and mental health.
\end{abstract}

\section{ABOUT THE AUTHOR}

This author remains anonymous. 